\title{
SECOND INTERNATIONAL EARTHQUAKE CONFERENCE APRIL 6-10 1987, LOS ANGELES, CALIFORNIA, U.S.A.
}

\author{
P.D. Leslie *
}

EDITORS' NOTE: This article is based on a report that was made by Mr Leslie to the Management committee. A selection of a few pages from some of the earthquake preparedness information collected by $\mathrm{Mr}$ Leslie (and referred to in section 11) is also included to give some idea of the range of material used in California.

1. The timing of the Second International Earthquake Conference in Los Angeles coincided with the study tour I was undertaking as part of the 1986 BRANZ award. This was to study overseas building control systems to assess their relevance for the revision of New Zealand's system of building controls. The conference was also timely as it was just one month after the New Zealand Edgecumbe Earthquake. I had been a member of the Earthquake Society's reconnaisance team to Edgecumbe and was therefore well placed to give a talk on the Edgecumbe earthquake.

2. The main objective of the conference was "to design a conference for the overall spectrum involved in earthquake research, mitigation, response, disaster preparedness and public education. The conference provided a forum for policy makers and administrators, educators, scientists, engineers, community activists and members of the business and industry to interface with each other and to discuss present and future needs. A further objective was that the conference should be useful in giving a practical perspective on the complex social, technical, administrative, political and economic challenges of forecasts preparation, response and recovery associated with earthquakes."

3. The conference was truly international with some 400 delegates from 30 countries. The countries included Indonesia, Canada, Chile, Columbia, Costa Rica, Cuba, Denmark, Dominican Republic, Ecuador, Egypt, El Salvador, Guatemala, Guinea (Africa). Haiti, Iceland, Jamaica, Jordan, Mexico, New Zealand, People's Republic of China, Peru, Puerto Rico, Saudi Arabia, Switzerland, U.S.A., and Venezuela.

Design Engineer, Lower Hutt City Council, Lower Hutt
4. The conference programme was divided into a number of themes each represented by separate sessions as follows:

- Assessment of seismic risk

- National earthquake programmes

- 8 concurrent "Break out" sessions Earthquake hazard analysis and mitigation - Response to earthquake prediction Urban search and rescue - Life lines/mitigation and recovery - Hazardous buildings: identification and retrofit Emergency medical services - School preparedness and education - Fire and hazardous materials

- Mexico City Earthquake of September 19 1985

- Media and Public Education

- Private Sector/Funding Educational Programmes

- Business and Industry Preparedness

- 7 concurrent "Break out" sessions Private sector funding - Protection of national treasures - Employee Education At work/At home - Earthquake preparedness in high rise buildings . - Company hazard reduction/Computer systems protection Mass care and shelter - California seismic safety commission meeting

- Government response

5. At the beginning of the conference the Conference Chairman, Councilman Hal Bernson stated that it was not proposed to have a written record of the conference. However, audio tapes of the various sessions would be available at a total cost of US\$185. Unfortunately, these are of rather limited value because there are no diagrams or pictures to assist the explanation. It was further explained that in order to foster interdisciplinary communicatlon that technical papers would not be published even if they had been prepared. Hal Bernson explained the conference committee's opinion that the requirement for the preparation of technical papers tended to dissuade some people from contributing. This was particularly so for people who may have only modest writing skills, yet have a valuable contribution to make concerning their experiences in an earthquake situation. Although there is some merit to 
this view, on balance I did not think it was a good idea not to allow those people such as myself who had prepared papers to make them available. This case for written papers is particularly strong in the situation with "Break out" sessions where there were eight concurrent sessions each with four or five speakers. It is obviously impossible to attend all presentations in

6. Although a relatively late entry, my presentation on "The Edgecumbe (New Zealand) Earthquake 1987" was included in the official conference programme. This paper was co-authored by John Hunt of Wellington City Council and John Morrison of Wellington Regional Council. There seemed to be considerable interest in the Edgecumbe Earthquake. In California there is a level of awareness and preparedness of earthquakes that is considerably higher than in New Zealand. Also news reports at the time of the Edgecumbe Earthquake were grossly exaggerated which appeared to heighten the interest in my presentation.

7. My presentation on April 6 was set down under the Session titled Hazardous buildings: Identification and retrofit. There were five speakers in this session. They included Earl Schwartz, Chief of the Resource Management Bureau, Department of Building and Safety, Los Angeles City, Dr Gary Hart, Professor of Civil Engineering, at the University of California, Los Angeles, Arq. Alberto Duque from the Department of the Federal District, Mexico, Michio Noma Director of the Association for Building Hazard Prevention in Japan and myself.

The papers were all interesting but unfortunately the chairmanship was substandard. Also all but one of the presenters had slides as part of their presentation, but the room could not be made sufficiently dark to do justice to the slides. My presentation was last and because of chairmanship problems somewhat restricted in time. However one advantage of being last was that by the end of the session efforts had been made to darken the room which made my slides somewhat clearer. It seems a poor show to me that at an international conference with speakers from three countries in my session alone that satisfactory facilities could not be provided for showing slides.

There was considerable interest in my presentation which was enhanced by the many excellent slides provided by BRANZ. At question time, because of time constraints I had time to answer only a small number of the questions.

8. As a result of this considerable interest in earthquakes in California and the Edgecumbe Earthquake, I was invited to appear on the CBS News programme. I appeared live for three minutes on the 6 o'clock news programme.

The interviewer was keen to learn the extent of damage caused by the recent New zealand earthquake, the experience gained and what lessons could be transferred to the California situation. Further, I was asked to comment on the measures being taken in California as compared with New zealand in mitigating the risk from earthquakes.

Although I did not see it personally, apparently parts of the interview were repeated later in the evening. As a result New Zealand Earthquake Engineers were given a relatively high profile in this earthquake prone city. In several later californian meetings related to my investigations on building controls, the people had knowledge of these television appearances.

9. Associated with the conference were a number of displays, of which I attended several.

One was a Yogi Bears Quakey Shakey van. This was a medium sized van which simulates earthquake motions by vibrating wildly when parked. It travels around the californian state to various places, such as schools, factories, offices etc so that people who have not experienced earthquakes can gain first hand experience. It is a interesting educational facility and was also much fun for the conference delegates.

I also attended a disaster preparedness and response exercise. This was set up on a lot at Universal Studios and gave the conference delegates the opportunity to view a disaster exercise.

10. I was somewhat disappointed in the engineering seismic design and experiences content of the conference. However from a perusal of the conference themes detailed in section 4 of this report, it is clear the conference aim was to cover considerably more than just technical engineering aspects of earthquakes. The conference was very useful from the point of view of making contacts.

These contacts were most helpful for my studies of overseas building control systems. Also since my return to New Zealand these contacts have been most useful for other New Zealand engineers going to california to study earthquake engineering and related matters.

11. I mentioned earlier in this report the high degree of preparedness for earthquakes of this part of the U.S.A.

I have a number of publications which show the broad spectrum of available earthquake preparedness information.

The information is impressive being targeted at the different language groups. It is also aimed at all age groups. For children, comics have been written using "Yogi the Be-Prepared Bear" by Hanna Babara on such topics as "Earthquake Preparedness for the Family", "Preparedness for Children" and "Creative First Aid, Yogi Bear Facts". At the other end of the scale the quarterly publication prepared by the 
Bay Area Regional Earthquake Preparedness Project is very informative.

Another example of material produced is the publication by The Federal Emergency Management Agency (FEMA) 46/October 1985 "Earthquake Safety Checklist". This appears to me to be a very useful publication which with minor adapation to New Zealand conditions could be publicised throughout New zealand by such agencies as Civil Defence Organisation or the Earthquake and War Damage Commission.

FEMA Publication No. 48 July 1986 - "Coping With Children's Reactions to Earthquakes and other Disasters" is also a very worthwhile publication which helps to prepare people for these major upheavals.

The American Red cross also produces a number of publications including "Safety and Survival in an Earthquake".

12. Although the incidence of earthquakes in New Zealand is not nearly as great as California I consider there is a need for greater preparedness. Disaster preparedness goes further than earthquakes and as the recent Gisborne/East Cape flooding experience shows, it is most necessary in a disaster situation to have supply of food and water. As you can see the California produced information covers these aspects. Feedback on possible dissemination of this information would be appreciated.

\section{CONCLUSIONS}

The benefits gained from my attendance at the second International Earthquake Engineering Conference sponsored by the city of Los Angeles are as follows:-

1. The contacts made at this conference have already heen invaluable for the development of earthquake engineering and related matters by New Zealanders.

2. My presentation on the Edgecumbe Earthquake was well attended and I am advised well received. This was no doubt assisted by the relatively high level of interest in earthquakes in California and by previous news reports of the Edgecumbe Earthquake.

3. The New Zealand engineering profession's expertise on earthquake engineering was given a high profile by my three minute live interview on CBS News.

\section{7 things to help you survive an earthquake}

Californians are constantly aware of the potential of an earthquake creating damage and creating dangerous conditions. So if we don't properly prepare, the next quake may cause greater personal damage than necessary. Each item listed below won't stop the next earthquake but it may help you survive in a better way.

\section{4 basies to do during an earthquake \\ 1. STAY CALM \\ 2. Inside: Stand in a doorway, or crouch under a desk or table, away from windows or glass dividers. \\ 3. Outside: Stand away from buildings, trees, telephone and electric lines. \\ 4. On the road: Drive away from underpasses/over- passes; stop in safe area; stay in vehicle.}

6asies to do after
an earthquake

2. Flashlight with extra batteries

3. First Aid Kit-including specific medicines needed for members of your household

4. First Aid book

5. Fire extinguisher

6. Adjustable wrench for turning off gas and water

7. Smoke detector properly installed

8. Portable fire escape ladder for homes/apartments with multiple floors.

9. Bottled water-sufficient for the number of members in your household

10. Canned and dried foods sufficient for a week for each member of your household. Note: Both water and food should be rotated into normal meals of household so as to keep freshness. Canned goods have a normal shelf-life of one year for maximum freshness.

11. Non-electric can opener

12. Portable stove such as butane or charcoal. Note: Use of such stoves should not take place until it is determined that there is no gas leak in the area. Charcoal should be burned only out of doors. Use of charcoal indoors will lead to carbon monoxide poisoning

13. Matches

14. Telephone numbers of police, fire, and doctor

3 things you need
to know

Los Angeles Chapter, 2700 Wilshire Blvd.

Los Angeles, California 90057, (213) 739-5200 Firn $\backslash(1,4)$. $15(4-80)$ 


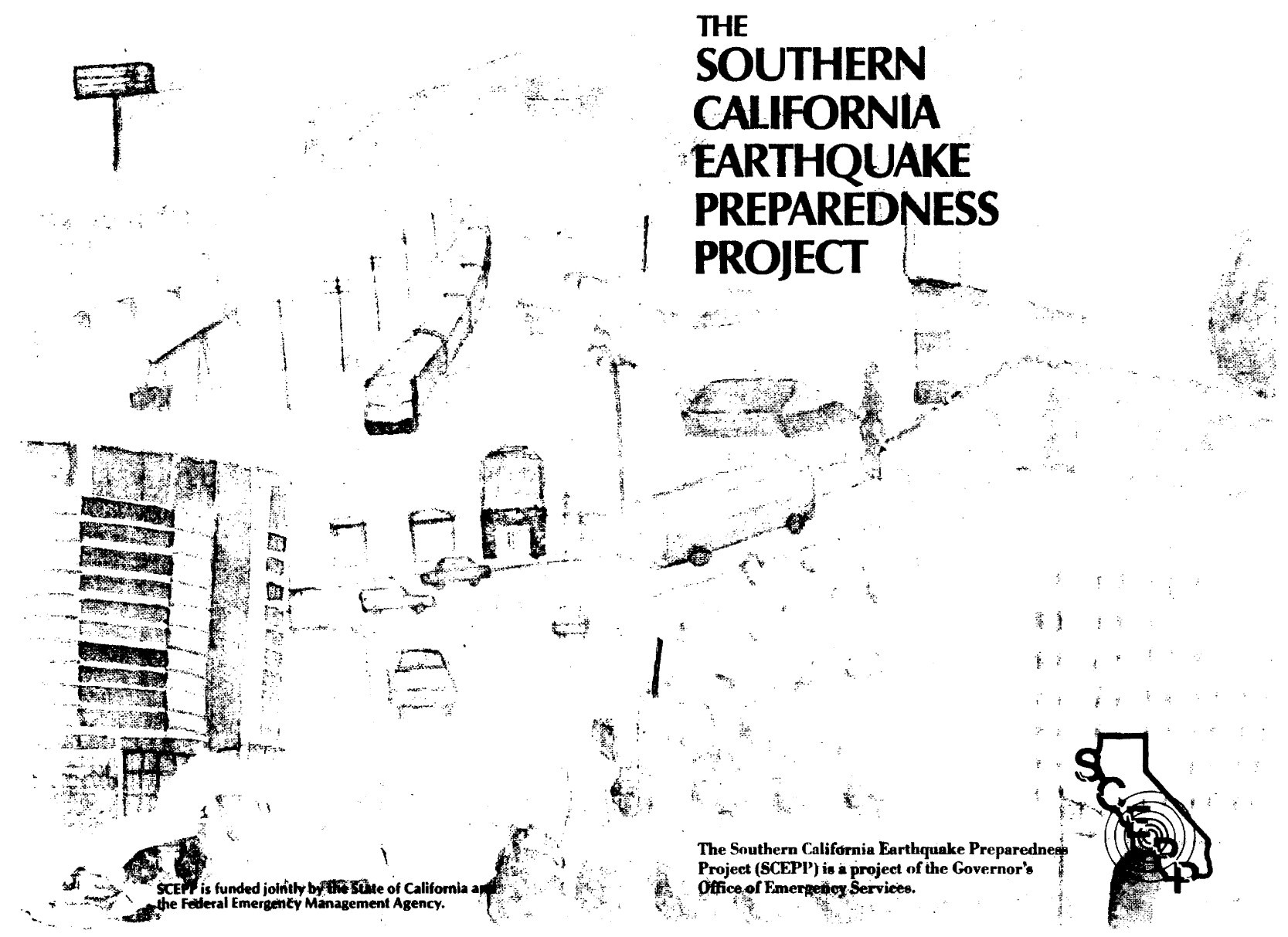

\section{Initiating an Earthquake Preparedness Program in Your Community}

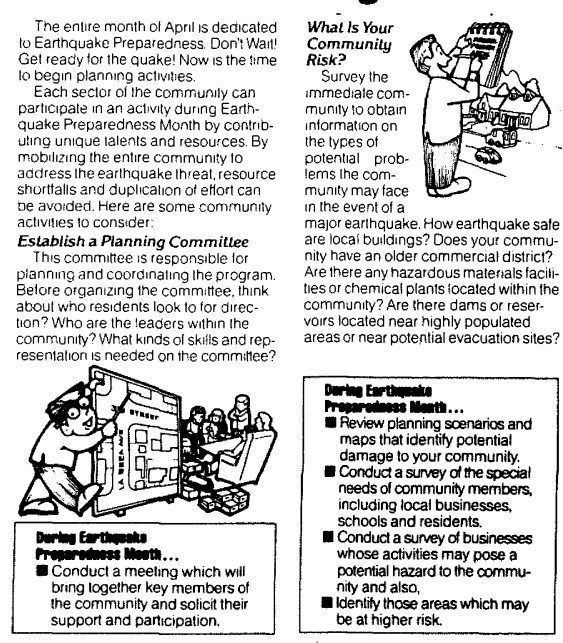

Los Angeles County to Adopt Five-Year Earthquake Preparedness Plan

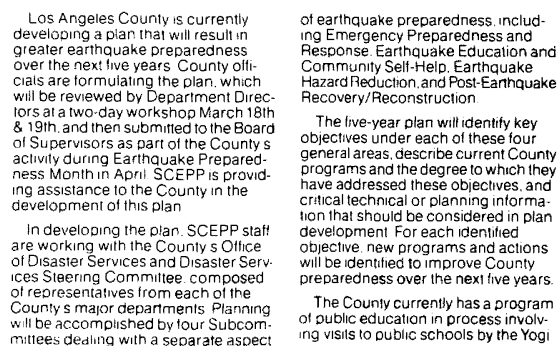

What Are Your Community

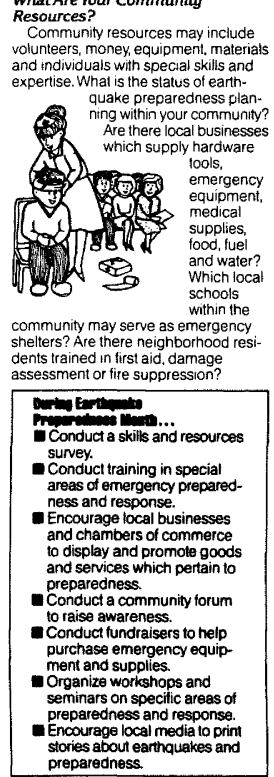

Bear Schoolhouse earthquake simu
lator. and is considering adoption of

lator. and is considering adoption of
a hazardous buildings ordinance to reduce structural earthquake hazaros
SCEPP and County staft will identity other areas that should be add ressed
or where further sleps can be taken. During Earthquake Preparedness
Month the Plan will be completed and tor appropriate action The result will be a significant slep lorward in earth
quake preparedeness tor the County

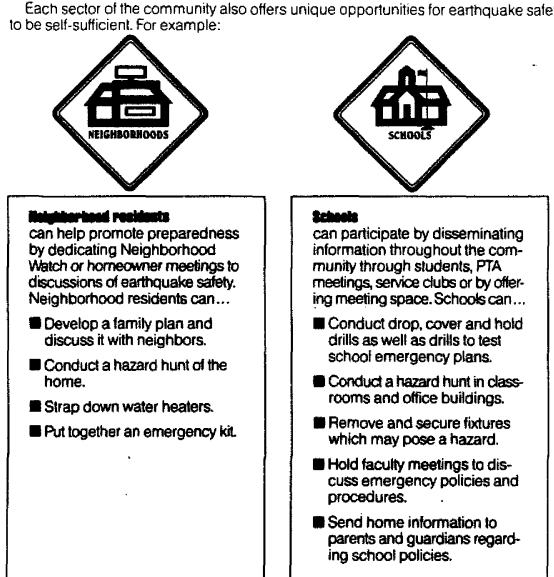

Rosearch Study Compares Community

Preparedness in Japan and California

Disaster research hndicales that
communtities which have experienced

generally have a greater awareness
the threat and take preparedness

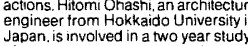

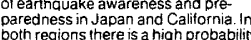

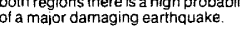

SCEPP is assisting Ohashis researc
effortsin southern Callornia anc has

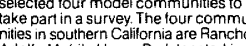

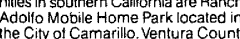

Yucaipa, a community localed in Sa
Bernardino County Desert Hot Springs

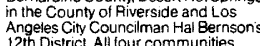

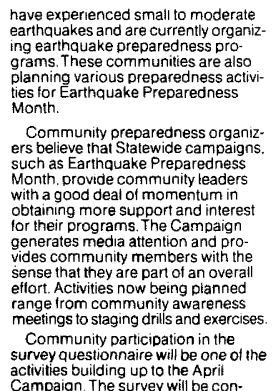

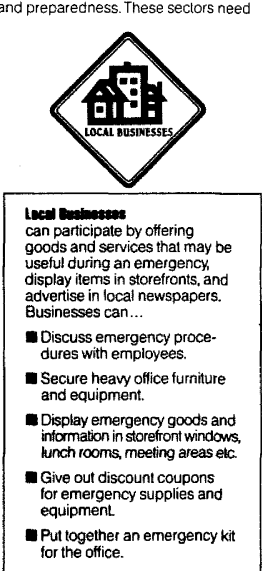

ducled rom January hrough March

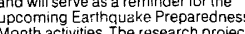
Month activitites The eresearch proiec
nitends to draw comparisons between evels of awareness and preparedness among communntites and cullures
Which share a similar earthauake intormation provivers gain a beter
understinding ol the current level awareness and preparedness amoln
neighbornoods so thal more eflective programs may be developed.
During this same period. SCEPP wII

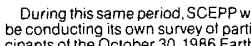

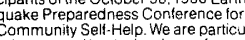
larly interessted in whether the conierence promoted partcipation in Earthquake
preparedness Monnth 1987 . In early February. a questionnaire was sent 1

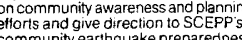
community earthquake preparedness 


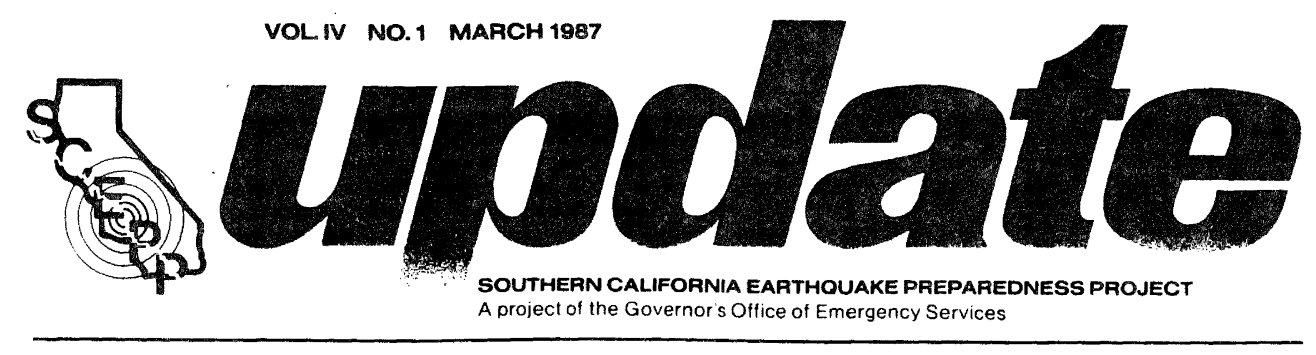

Governor George Deukmejian has proclaimed April, 1987 as California
Earthquake Preparedness Month. The
move to expand the campaign to a fullmove to expand the campaign to a full-
scale month was initiated to allow for
greater participation of different groups and organizations in the campaign's activities, and to demonstrate the high priority of renewed earthquake
preparedness efforts. The focus of this year's campaign is to educate the
public on the importance of earthquake preparedness and to encourultimately prepare them for a major damaging earthquake. In planning for this year's
campaign, the Governor's Of-
fice of Emergency Services has fice of Emergency Services has and communications firm in northern California, to assis with the organization and im-
plementation of Earthuake Preparedness Month. A major
product resulting from this conract is a final workplan for th ness Month. Strategies and recommendations proposed in
the workplan are partially based on information from a survey ipated in previous earthqual
preparedness campaigns.

preparedness campaigns.
The theme of this year's campaig
"Dot "Don't Wait...Get Ready for the Quake" take action to prepare their homes, businesses, schools, and other locations for a possible earthquake dis-
aster. The July, 1986 earthquakes in Palm Springs, Oceanside, and Bishop Calitornia reflected the increasing
seismic activity in our state, and reinforces the need for on-going public awareness campaigns to promole communities.

APRIL 1987 CALIFORNIA EARTHOUAKE PREPAREDNESS

Month Campaign. Local participants
will receive reproducible copies of the fact sheets or a limited number of

printed fact sheels. OES will be dispaign theme and logo, and a statewide during Earthquake Preparedness Month. This calendar will be included be sent tor ment offices.

\section{MONTH} The primary strategy for outreach and dissemination of these informaducted through the key association-

This year's campaign will target eight safety, health and emergency planner: school children, teachers and princi-
pals; persons with disabilities; busiDe)

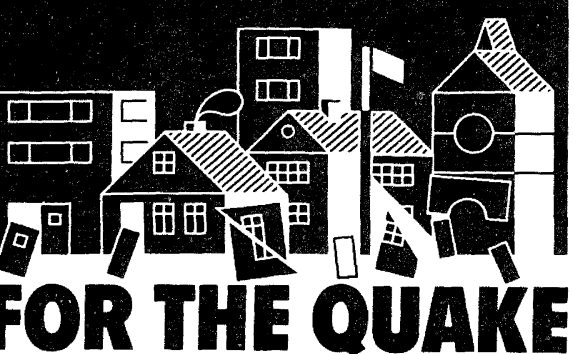

of the eight target groups, such
as apartment and mobile home. as apartment and mobile home
owners associations, various disaster relief organization
(such as the American Red Cross), special interest groups,
state legislators, mayors and city council members, as well as many others. Through the participation and support of
these groups, SCEPP, BAREPP constituents with informatio about the earthquake threa
and the many steps they can undertake to protect the h-rise office buildings: government employees; people who owners, mobile home, and apartment dwellers.

In order to help promote the cam-
paign, OES, SCEPP and BAREPP will be distributing a program folder. The tion on various subjects, including the earthquake threat, the importance of tion tor aphquake prepared, intormarise office managers and owners, and suggested local activities for school, business and government involve-
- 10 the month's events there be a theme for each week of the month: Week 1: Wednesday, April 1 Earthquake Preparedness Month Kick-Off," promoting media coverage on the earthquake threat, and the earthquakes. Week 2: Monday, April 6 through Sunday, April 12-"School Cooperation Week." Week 3: Monday, April 3 through Sunday, April 19Week 4: Monday Apri20 throk" Sunday, April 26-"Home and Neighquake preparedne and family earth quake preparedness for those who
reside in apartments, mobile homes reside in apartm
Continued on $p .7$ generic tact sheets covering informa borhood Preparedness Week," which

\section{BAY BEROT EARTHOUAKE UPDATE}

Governor Signs

Hazardous

Building Bill

On July 2. 1986, in a precedent setting action. Governor Deukmejian
signed SB 547 into law (Chapter 250). This law requires local governments to
conduct inventories of all unreinforced masonry buildings in their jurisdictions. Once the inventories are complete loca governments are required to develop
mitigation programs for these buildings. Inventories and mitigation programs must be completed by 1990 . The law authorizes local building depart-
ments to establish a schedulc of fees to recover the costs of identifying potentially hazardous buildings and carrying out other requirements of the law. The new state law defines potentially

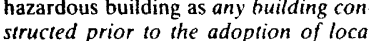
building codes requiring earthquake re sistant design of buildings and constructed of unreinforced masonry wall construction. Potentially hazardous ters, places of public assembly. ment buildings, hotels, motels, fire stations, police stations, and buildings housing emergency services, equipment, in supplies, such as government bulldcations facilities, hospitals, blood banks, pharmaceutical supply warehouses. plants, and retail outlets. For the purnot include warehouses or s tures not used for human habitation, except for warehouses or structures housing emergency services equipmen or supplies, nor does if include any building having five living units or less.
Several California communities, recognizing that this is an important problem, had developed programs prior to the passage of this law. Los Angele developed a program in 198. Unde require some type of rehabilitation or will need to be torn down. The Mexico City earthquake prompted acceleration bre prom. ordinance developed by the Seismic Safety Commission. Long Beach has had an ordinance in place since 1971. In the Bay Area, Santa Rosa has a hazardous building ordinance as do
Sebastopol, Palo Alto and Morgan Hill.
San Francisco is in the process of developing a program which may also gram has several unique features, including the fact that it does not foc and it attempts to persuade property owners to rehabilitatc buildings, rather than mandating such rehabilitation. By September 1987 the Seismic Safey Commission, in coopcration with the Supervisors Association, and California Building Officials will prepare an dvisory report for local jurisdictions

\section{Business Survey}

A recent survey indicates little attention to earthquake recovery planning businesses who had shown some past interest in earthquake preparedness responded. The following summarizes pertinent results.

Level in Company Where Overall Earthquake Planning Responsibility Lies. Top Management

Staff

Level of Response and Recovery Planning.

Response:

Does your company have a safety committee? Does your company have an earthquake/disaster response plan?

Do you store emergency supplies on site? Has your

Have you surveyed the interior of your building for

training program for earthquake preparedness?

Recovery:

Have you developed any alternate site production plans in the event your building is inaccessible followin

Have you established alternate delivery schedules or other arrangements with vendors or clients?

Have you developed a plan for informing clients, the general public and media about company operation

Have you developed procedures to protect vital record

These results reflect responses from businesses who, in some way, gre already cognizant of the earthquake threat and have shown past interest in
developing earthquake programs in their companies. 


\section{earthquakes \\ safety tips for earthquakes}

\section{The earthquake potential}

Earthquakes in the United States occur most tre. quently west of the Rocky Mountains. But there are 39 states with a cumulative population of
more than 70 million which are potential targets for earthquakes.

\section{What to expect \\ in an earthquake}

During an earthquake, the "solid" earth moves like the deck of a ship. The actual movement of death or injury. Most casualties result from falling objects and debris because the shock can shake, damage, or demolish buildings. Earthquakes may also trigger landslides, cause fires. and generate huge ocean waves called is

Earthquake injurles are commonly caused by:

- building collapse or damage, such as toppling chimneys, falling bricks from wall facings and roof parapets, collapsing walls, tures.

- flying glass from broken windows. (This danger may be greater in modern, high-ris structures.)

- overturned bookcases, wall units, and other furniture.

- fires from broken chimneys, and ruptured gas and electrical lines. The danger may be aggravated by a lack of water caused by broken mains.
- fallen powerlines

- drastic human actions resulting from fear.

\section{Before an earthquake}

Check your home for potential hazards.

- Defective electrical wiring and leaky cas or inflexible connections are very dangerous
in the event of an earthquake. Bolt down water heaters and gas appliances.

- Know where and how to shut off electricity. gas, and water at main switches and valves. Check with your local utilities tor in

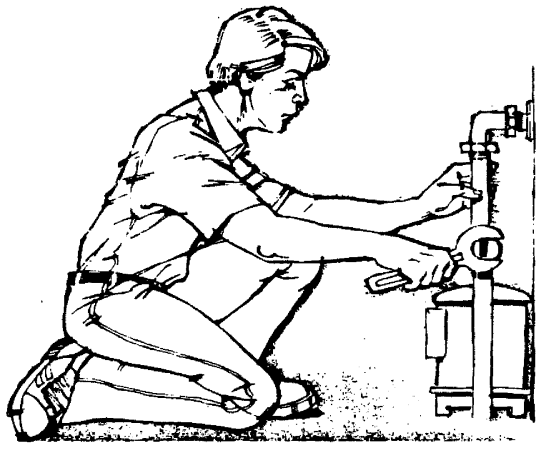

- Place large and heavy objects on lowe shelves. Securely lasten shelves to walls. Brace or anchor high or top-heavy objects.

- Bottled goods, glass, china, and other breakables should be stored in low or closed cabinets.
- Overhead lighting fixtures such as chandeliers should be made fast. A little wiring or risks.

- Deep plaster cracks in ceilings and founda. tions should be investigated and repaired. Hold occasional drills so each member of your family knows what to do in an earth. quake.

Teach responsible family members how to switches and valves.

\section{Have on hand:}

- a flashlight and battery-powered radio in case power is cut off.

- a supply of drinking water and some nonperishable foods which can be pre pared without cooking.

- a fire extinguisher and first aid kit.

\section{During an earthquake}

First and foremost, stay calm. Think First and foremost, stay calm. Think
through the consequences of any action you take.

If you are inside, stay inside; if you are outdoors, stay there. In earthquakes, most injuries occu If indoors, take cover under a heavy desk, table. side wall Stay away from glass. olong an in. candles, matches, or other open flame eithe during or after the tremor because of possible gas leaks. Douse all fires.
If in a high-rise building. get unas' a desk or similar heavy lurnilure. Do not dzsh for exits. peop. Never use be broken anc jammed with sincs power may

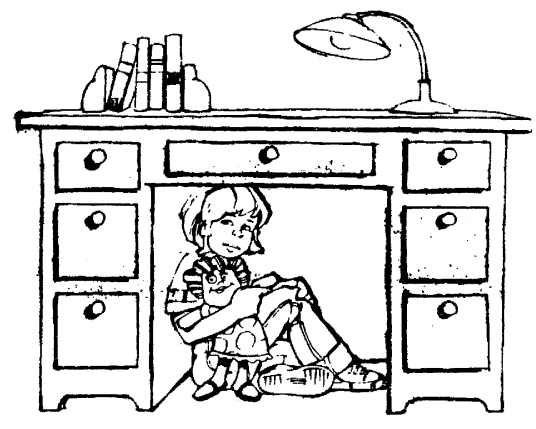

If outdoors, move away from buildings and utility wires. The greatest danger from fal !ng debris is Once in the open, stay there until the shaking stops.

If in a moving car, stop as quickly as safety permits, but stay in the vehicle. $\mathrm{A}$ car may jiggle violently on its springs, but it is a good place to stay until the shaking stops. When you drive on, wach tor hazards creaps. Wh the earthquake, wires, or broken or unobjects, downed electric 

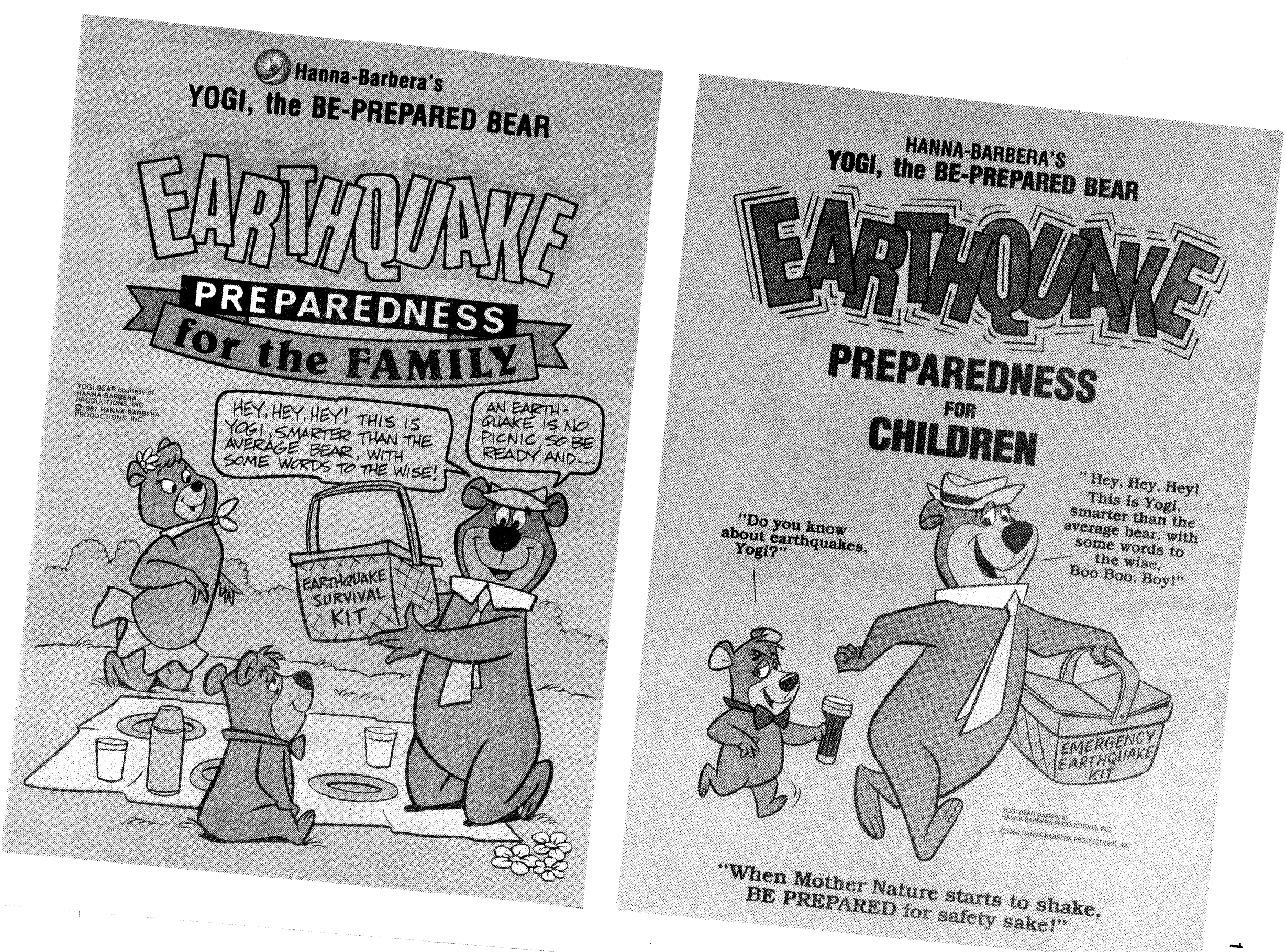
You live with the threat of earthquakes every day. Chances are that you haven't done anything to prepare

$$
\text { for one. }
$$

That's too bad.

Because in an hour or two, you can take steps to protect your family and also limit the damage to your home and property.

\section{Read the brochure.}

Take the steps.

Someday, possibly tomorrow

you'll be glad you did.

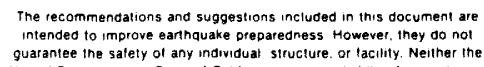

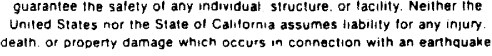

Based on Material

Developed by The Southern California Earthquake Preparedness Project

143/ SFPTFMRFR 1986

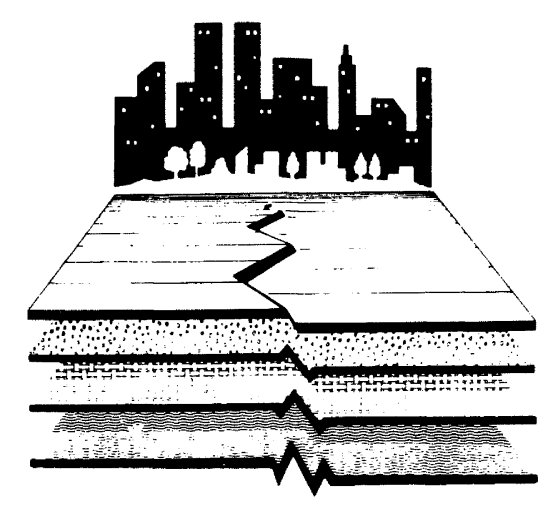

PREPAREDNESS IN APARTMENTS AND

\section{MOBILE HOMES}

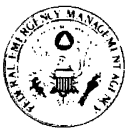

\section{WHAT TO DO ABOUT IT} secure them. Remove your bed. Objects can be secured with wire, heavy

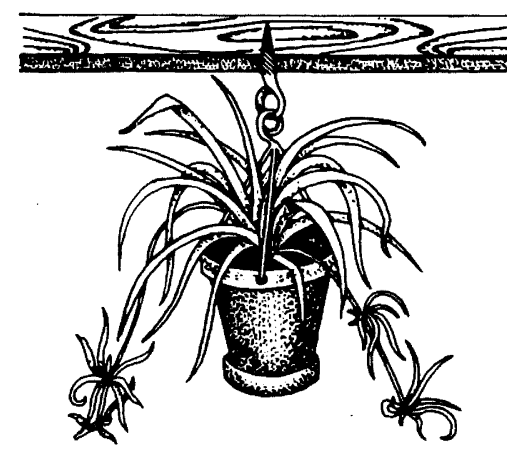

Secure hanging plants.

into wood, not just the plaster, then simply bend the hook shul with a pair phers, or close ll by wrappling wire around. Also, heavy ceramic ones.

\section{SECURE OTHER \\ DANGERS}

Objects can be secured to the wall to keep them from falling.

Check with your manager first if you rent an avorid it.

Top-heavy furniture, appliances, pictures and mirrors can all be secured by fastening them into the wall with screws. Allacive positive-close latches. board contents from falling ou in an eartavake.

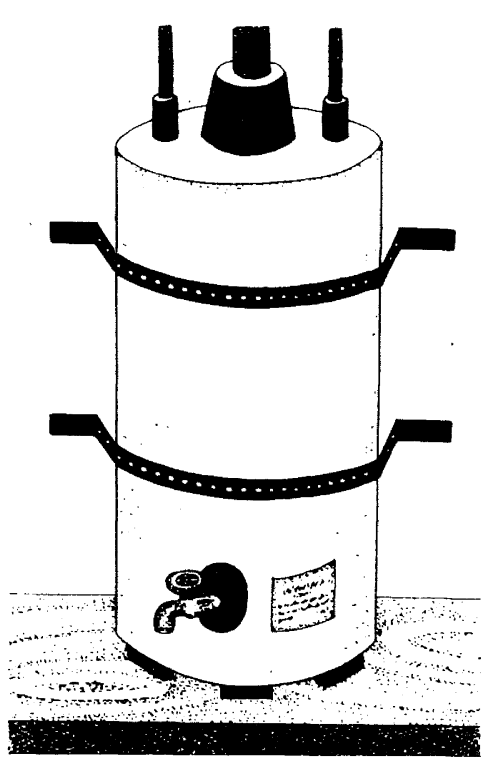

ABOUT WATER HEATERS...

Most mobile homes and many apartments hav They should be secured event them from

Metal plumber's tape wrapped around the heater then secured into a support in the wall is an you may have solf and your tamily (to vithdraw water. your

If you live in an apartment that has a central water heater, it can be secured as well, eliminating
fire danger and assuring a water supply. Ask your manager about your apartment's plans. 